\title{
Bloedite sedimentation in a seasonally dry saline lake (Salada Mediana, Spain)
}

\author{
Florias Mees $^{\mathrm{a} *}{ }$, Carmen Castañeda ${ }^{\mathrm{b}}$, Juan Herrero $^{\mathrm{b}}$, Eric Van Ranst ${ }^{\mathrm{c}}$ \\ ${ }^{a}$ Department of Geology and Mineralogy, Royal Museum for Central Africa, \\ Leuvensesteenweg 13, B-3080 Tervuren, Belgium. \\ ${ }^{\mathrm{b}}$ Department of Soil and Water, Estación Experimental de Aula Dei, CSIC, PO Box \\ 13034, 50080 Zaragoza, Spain. \\ ${ }^{c}$ Department of Geology and Soil Science, Ghent University, Krijgslaan 281 S8, B- \\ 9000 Ghent, Belgium. \\ * Corresponding author.
}

\begin{abstract}
Salt crusts covering the surface of the Salada Mediana, a seasonally dry saline lake in northern Spain, consist predominantly of bloedite $\left(\mathrm{Na}_{2} \mathrm{Mg}\left(\mathrm{SO}_{4}\right)_{2} \cdot 4 \mathrm{H}_{2} \mathrm{O}\right)$. Microscopic features of the crust were investigated to understand processes of bloedite sedimentation. This study was combined with satellite and airborne observations, revealing asymmetrical concentric and parallel-linear patterns, related to wind action. Gypsum $\left(\mathrm{CaSO}_{4} \cdot \mathrm{H}_{2} \mathrm{O}\right)$ and glauberite $\left(\mathrm{Na}_{2} \mathrm{Ca}\left(\mathrm{SO}_{4}\right)_{2}\right)$ in the calcareous sediments below the crust, and abundant eugsterite $\left(\mathrm{Na}_{4} \mathrm{Ca}\left(\mathrm{SO}_{4}\right)_{3} \cdot 2 \mathrm{H}_{2} \mathrm{O}\right)$ along the base of the crust, largely formed at a different stage than bloedite. The main part of the crust consists predominantly of coarse-crystalline xenotopic-hypidiotopic bloedite, but fan-like aggregates with downward widening, radial aggregates, surface layers with vertically aligned elongated crystals, and partially epitaxial coatings occur as well. The upper part of the crust is marked by a bloedite-thenardite $\left(\mathrm{Na}_{2} \mathrm{SO}_{4}\right)$ association, recording a change in brine composition that is not in agreement with results of modelling of local brine evolution. A thin fine-grained thenardite-dominated surface formed in part by subaqueous settling of crystals, but there are also indications for development by transformation of bloedite. Surface features include fan-like bloedite aggregates with upward widening, formed by bottom growth. Overall, the Salada Mediana crusts record a complex history of bloedite and thenardite precipitation by various processes.
\end{abstract}

Keywords : bloedite, thenardite, evaporites, saline lake 


\section{Introduction}

Bloedite $\left(\mathrm{Na}_{2} \mathrm{Mg}\left(\mathrm{SO}_{4}\right)_{2} .4 \mathrm{H}_{2} \mathrm{O}\right)$ is a common constituent of sodium sulfate deposits (Garrett, 2001; Warren, 2006, 2010), which typically form in non-marine environments. Known major deposits with high bloedite contents are mainly Quaternary to recent, with main occurrences in northern Mexico (Laguna de Rey; SánchezMejorada, 1986), the Caspian Sea region (Kara Bogaz Gol; Karpychev, 2007), and western Canada (e.g. Last and Ginn, 2005). Textural features of these and other subaqueous bloedite accumulations have hardly been documented, and only scattered textural data are available for bloedite occurrences as part of salt crusts on soils (Mees and Tursina, 2010). In principle, petrographical data can provide important information about various relevant aspects of salt accumulations, such as mineral precipitation mechanisms, depositional sequences, and diagenetic change. For bloedite-rich formations, textural studies could be applied to extract more information from salt beds in lacustrine sequences that have been targeted for palaeolimnological research (e.g. Last, 1990, 1993; Sack and Last, 1994; Li et al., 2010), and to obtain a better understanding of the origin of poorly documented sodium sulfate deposits of economic value (e.g. Bertram, Laguna de Rey; see Garrett, 2001). For soil environments, possible applications include the assessment of the role of flooding and other processes in the formation of bloedite-bearing surface crusts (e.g. Vizcayno et al., 1995; Mees and Singer, 2006). The present study aims to contribute to the current knowledge of textural features that is required for these applications, by studying salt crusts from a presentday saline lake basin. In more general terms, it is also a study aimed at enhancing the present understanding of ephemeral saline lake sedimentation, for which the significance of petrographical features has been demonstrated for specific types of salt accumulations (e.g. Lowenstein and Hardie, 1985; Mees, 2001).

The Salada Mediana, also known as La Sulfúrica, is a seasonally dry saline lake in the arid central Ebro Basin, northern Spain $\left(41^{\circ} 30^{\prime} \mathrm{N}, 0^{\circ} 44^{\prime} \mathrm{W}, 25 \mathrm{~km}\right.$ SSE of Zaragoza), for which the occurrence of bloedite-dominated salt crusts has been documented. The presence and nature of salts in this basin are described in a number of earlier publications, comprising regional studies with mineralogical data for the surface crusts and the underlying sediments (Pueyo-Mur, 1978/1979; Mingarro et al., 1981), and palaeolimnological studies that include some information about the uppermost part of the deposits (Pérez et al., 1998; Valero-Garcés et al., 2000a, 2000b). One 
experimental study using local brines also provides data for the natural crusts (Auqué et al., 1995). All mentioned studies present some mineralogical and chemical data, used to discuss brine evolution and salt formation in the basin. The present study concentrates on textural features of the crust, aimed at understanding processes of bloedite accumulation. Supplementary data on crust development were derived from satellite and airborne observations.

\section{Materials and methods}

The lake basin was visited at the end of the dry season (September), following a period with only occasional local rainfall $(<8 \mathrm{~mm}$ distributed over four days in the month before sampling, no rainfall in the week before sampling, $191.3 \mathrm{~mm}$ evaporation during the same month; data available from the SIAR network of meteorological stations - Sistema de Información Agroclimática para el Regadío, Ministerio de Medio Ambiente y Medio Rural y Marino, Spain). On-site inspection of the salt crusts was later extended using orthophotographs and a SPOT-5 image furnished by the Plan Nacional de Teledetección (Instituto Geográfico Nacional, Spain). The four orthophotographs that were analyzed $(0.5$ to $1 \mathrm{~m} /$ pixel $)$ represent conditions in October 1997, June 1999, August 2006, and June 2009. The satellite image (2.5 m/pixel), acquired 25 days after the sampling date, contains the panchromatic and multispectral bands, fused using a fast HIS transform (González-Audícana et al., 2006).

Three sites with different surface characteristics were sampled, as described below. Two to four samples, representing specific features, were collected at each site. Most samples include some material adhering to the base of the salt crust, derived from the underlying fine grained sediment substrate. A total of 15 thin sections were prepared (mainly 6 by $9 \mathrm{~cm}$ large), after impregnation with a cold-setting polyester resin, avoiding all contact with water. Mineral identification was confirmed for selected samples by XRD analysis of powders (Philips X'pert System; CuK $\lambda$ 3-60 $2 \theta, 0.02^{\circ} 2 \theta$ . step size, $1 \mathrm{sec} / \mathrm{step})$.

\section{Setting}


The Salada Mediana is located in an area characterized by a dense network of flat-bottomed valleys that are weakly incised in a Miocene substrate (Zaragoza Gypsum Formation) (Fig. 1). The latter consists of a sequence of gypsum, mudstone and marl beds (Quirantes, 1978; Marqués et al., 1991), and it is know to contain halite and glauberite in some areas (Salvany, 2009). The lake is located in the Quaternary sediment fill of a valley, where it occupies a karstic depression whose formation is structurally controlled.

The lake is a discharge basin that is nearly exclusively groundwater-fed, without organized surface drainage towards the depression and with only minor contributions from direct rainfall and run-off (Pérez et al., 1998). The lake is dry in summer but the basin floor is covered by surface brines during other parts of the year, with up to about $50 \mathrm{~cm}$ thickness of the brine layer (Pérez et al., 1998). Average annual values of relevant meteorological parameters for the area, for the period 2005-2010, are $259 \mathrm{~mm}$ precipitation, $1406 \mathrm{~mm}$ reference evapotranspiration, $15.0^{\circ} \mathrm{C}$ mean temperature, $64 \%$ relative humidity, and $2.6 \mathrm{~m} \mathrm{~s}^{-1}$ wind speed at $2 \mathrm{~m}$ above ground (SIAR data, Ministerio de Medio Ambiente y Medio Rural y Marino, Spain). Scattered data on brine composition can be found in various reports, all confirming a $\mathrm{Na}-\mathrm{Mg}-\mathrm{SO}_{4}-(\mathrm{Cl})$ composition (Pueyo Mur, 1978/1979; Mingarro et al., 1981; Auqué et al., 1995; Pérez et al., 1998; Valero-Garcés et al., 2000a; López and Mandado, 2007).

\section{Results}

\subsection{Field characteristics, satellite and airborne observations}

Throughout the basin, the floor of the depression is covered by a salt crust, with a superimposed coarse $(>1 \mathrm{~m})$ polygonal cracking pattern. Site 1 represents the part of the basin where the surface is most whitish and where the crust seemed to have the greatest thickness (up to $1 \mathrm{~cm}$ ) (Fig. 2a). At this site, the crust comprises a thick discontinuous surface deposit (up to $5 \mathrm{~mm}$ ), with a horizontal planar surface and irregular patterns in plan view, that rests on an undulating more greyish basal layer (Fig. 2b). Locally, a much thinner continuous horizontal plate (1-2 $\mathrm{mm})$ overlies the crust in this part of the basin. At site 2, small surface accumulations (ca. $30 \mathrm{~cm}$ ) of white salts are common, rising up to $1 \mathrm{~cm}$ above the greyish crust that covers the basin floor outside these structures (Fig. 2c). Site 3 represents a more marginal part of the basin, 
with a thin greyish crust (up to $3 \mathrm{~mm}$ ) that has an irregular surface (Fig. 2d). At sites 2 and 3, fine-grained white material forms a thin discontinuous coating of the irregular surface. Equant small white salt aggregates $(1 \mathrm{~cm})$ locally cover the surface at site 3 .

Dry surface conditions during sampling are revealed by the SPOT-5 (RGB 432) image. Rainfall during the period between sampling and the acquisition of this image (7.1 $\mathrm{mm}$ distributed over four days during the 25-day period) is largely exceeded by local evaporation. The mean of maximum daily wind velocity, predominantly from the north-west, was $7.5 \mathrm{~m} \mathrm{~s}^{-1}$, with an absolute maximum of $12.6 \mathrm{~m} \mathrm{~s}^{-1}(2 \mathrm{~m}$ above soil surface) (SIAR meteorological data, Ministerio de Medio Ambiente y Medio Rural y Marino, Spain).

Near-surface brines, wet sediments, and salt minerals with structural or absorbed water will yield low reflectance values, especially in the near- and middle-infrared regions, giving rise to dark areas in satellite images that include infrared bands. For the Salada Mediana basin, zoning is apparent, with a peripheral zone where the basin floor is dry and free of surface salts (reddish areas), zones with high reflectance that correspond to spectrally dry salt crusts (whitish areas), and zones with lower reflectance indicating high moisture contents and limited salt crust thickness (dark areas) (Fig. 3a). ISODATA classification of the satellite image (Fig. 3b), combined with spectral analysis, reveals a moisture distribution pattern described as a playa-lake facies for similar environments (Castañeda et al., 2005; Díaz de Arcaya et al., 2005). Six moisture classes are delimited for the basin floor (Fig. 3b), comprising dry soil (class 1) and dry to very wet salt crusts (classes 2 to 6), the latter characterized by a decrease in reflectance and by changes in slope of the spectral signature with increasing moisture content.

Two main patterns are observed in all or most orthophotographs, i.e. concentric and parallel-linear patterns (Fig. 4), as described below. In one image, without lineaments, large desiccation polygons are visible (2-10 m diameter) (Fig. 4c).

Images for all dates examined show a quasi-concentric arrangement of salt fringes that is highly asymmetrical with more compressed banding along the eastern border. The 1999 image shows the presence of shallow standing water, greenish due to algae or cyanobacteria, with a local associated extension over the salt crust along its western margin (Fig. 4b). The colour of the basin floor in these images depends on crust thickness and texture. Outside the zones with a massive thick crust (white areas) (Fig. $4 \mathrm{c}$, and $\mathrm{d}$ ), the crust is thinner and the underlying black lacustrine mud becomes visible 
(dark areas) (Fig. 4d). The dark tone of the 2009 photograph (Fig. 4d) illustrates the higher moisture content around the zones with a dry massive crust. The maximum extent of the wet fringe is observed for the area where the main run-off inlet reaches the lake (Fig 4c). The dry soil along the border of the basin appears as an external fringe with high reflectance (whitest area in Figure 4b; also class 1 in Figure $3 b$ ).

A conspicuous pattern of parallel bands is superimposed on the concentric patterns, crossing the concentric fringes (Fig. 4a, b and d). These lineaments are streaks along which surface salts have been removed, reaching the underlying dark wet sediment substrate where the bands are well-developed. A higher density of lineaments is observed for areas where the crust is thin (dark areas, Fig. 4b), but they also occur in zones with a dry thick crust (Fig. 4d).

\subsection{Microscopic features}

In thin sections, all samples show the same sequence of units, as described below. From bottom to top, they comprise (i) fine-grained sediment adhering to the base of the crust, with some glauberite $\left(\mathrm{Na}_{2} \mathrm{Ca}\left(\mathrm{SO}_{4}\right)_{2}\right)$ and gypsum $\left(\mathrm{CaSO}_{4} \cdot 2 \mathrm{H}_{2} \mathrm{O}\right)$, (ii) the main part of the crust, consisting of bloedite, (iii) the upper part of the crust, with a bloedite-thenardite $\left(\mathrm{Na}_{2} \mathrm{SO}_{4}\right)$ association, (iv) a thin microcrystalline thenardite layer, and (v) local bloedite overgrowths.

\subsubsection{Material below the crust}

The sediment below the crust consists of fine-grained calcareous material, with micritic carbonates (calcite, dolomite) and scattered silt- to fine-sand-sized quartz grains. Common salt mineral occurrences are euhedral glauberite crystals and tabular gypsum crystals (Fig. 5a). A glauberite-bearing interval occurs above a level with gypsum crystals in one sample. Bloedite is commonly present, in one sample as subhedral crystals that enclose some gypsum (Fig. 5b). In another sample, a discontinuous band of mainly elongated bloedite crystals occurs near the base of the unit, including radial aggregates and fan-like intergrowths with inward widening (Fig. 5c). Elsewhere, bloedite occurs as radial aggregates of more acicular crystals (Fig. 5d). Traces of halite $(\mathrm{NaCl})$ are detected by XRD analysis, but no occurrences are observed in thin section. 
Between the sediment and the base of the overlying salt crust, an interval with acicular eugsterite $\left(\mathrm{Na}_{4} \mathrm{Ca}\left(\mathrm{SO}_{4}\right)_{3} \cdot 2 \mathrm{H}_{2} \mathrm{O}\right)$ is generally recognized, with common radial aggregates of this mineral and a minor admixture of calcareous fine sediment (Fig. 5e).

The material below the crust is covered by bloedite coatings in part of several samples. They occur along the base of samples of upturned polygon edges, along the top of the interval where the crust became separated from the substrate, and along the sides of pores within the adhering material (Fig. 5f).

\subsubsection{Main part of the crust}

The main part of the salt crust consists exclusively of bloedite. The crystals are generally anhedral to subhedral, with common elongated forms. Most samples include fan-like aggregates of elongated crystals, typically with downward widening of the intergrowth (Fig. 6a). These aggregates range from intergrowths of wide elongated crystals to fine-fibrous aggregates showing rolling extinction.

The unit generally contains a considerable amount of sediment as inclusions in the bloedite crystals. At site 1, the sediment content is much lower in the upper part of the unit, which partly represents the lower part of wide protrusions along the surface of this part of the crust (see Fig. 7c). These protrusions are the basal, often bridging, part of the discontinuous surface deposits with a horizontal surface that are recognized in the field. In thin sections, these deposits appear as protrusions of the main part of the crust, with lateral extensions at the top that are separated from the main crust. The boundary between the sediment-rich and -poor parts is generally diffuse, and it locally crosses large crystals and fan-like aggregates (Fig. 6b). A high sediment content is also confined to the lower half of one radial aggregate. Within the part with a high sediment content, large pores are commonly lined by sediment-free bloedite coatings, whose constituent crystals are at least in part in optical continuity with the surrounding bloedite (Fig. 6c). In the same part of the crust, some crystals show zoning with variations in sediment content. Along the base of the crust, bloedite can enclose glauberite crystals where the latter are present in the underlying substrate (Fig. 6d). A common feature is the presence of eugsterite inclusions (Fig. 6e), both in the part with a high sediment content and in higher parts of the unit.

In one site 3 sample, the main part of the crust comprises a relatively finegrained surface layer of subvertical elongated bloedite crystals, commonly occurring as fan-like intergrowths with upward widening (Fig. 6f). The base of this layer is lined by 
a thin band with sediment inclusions. Parallel alignment of relatively small elongated crystals is also recognized along the surface of two other samples (sites 2 and 3 ).

\subsubsection{Upper part of the crust}

The upper part of the crust is marked by the presence of thenardite (Fig. 7a), whose abundance is greatest at site 1 . At both other sites, the equivalent interval is a poorly delimited upper part where some scattered thenardite crystals occur within the bloedite mass, whereby the thenardite content is greater at site 2 than at site 3 . The thenardite crystals are commonly subhedral to euhedral, in contrast to the associated bloedite crystals. Little or no sediment is enclosed in this part of the crust. Acicular eugsterite inclusions are common, both in thenardite and in bloedite (Fig. 7b).

At site 1, thenardite occurs exclusively in the upper part of the wide protrusions that are recognized (Fig. 7c). Elsewhere at the same site, the thin horizontal plate that locally overlies the crust is present in thin sections as a bloedite-thenardite deposit that is separated from the bloedite-dominated main part (see Fig. 8e), as equivalent of the upper part of the crust in other samples.

Another correlatable occurrence are the local thick salt accumulations at site 2, consisting of a loose accumulation of bloedite and thenardite (Fig. 7d). In these structures, bloedite is more fine-grained than in the underlying massive crust, and it partly occurs as radial aggregates. Similar material occurs locally along the surface of two site 3 samples, representing the white surface aggregates recognized in hand specimens.

\subsubsection{Surface layer}

The crust is covered by a thin layer of fine-grained thenardite (Fig. 8a). In a few samples, this unit may include some associated equally fine-grained bloedite throughout the layer. The surface layer partly covers the irregular surface of the crust, including the subvertical sides of the wide protrusions (Fig. 8b). Locally, the surface layer separates from the crust as bow-like sections. The same type of fine-grained thenardite deposit covers the base of one polygon edge sample, which does not include any adhering material along the base.

In several samples, surface layer material partly occurs as a thin horizontal layer that extends over the space between neighbouring protrusions and over smaller depressions (Fig. 8c). At site 1, the plate-like upper part of the crust is a hollow 
structure, extending from the protrusions, that is lined on all sides by a thin fine-grained thenardite layer (Fig. 8d). A similar layer completely surrounds the thin bloeditethenardite plate that locally covers the crust at site 1 , separated from the surrounded plate in large parts (Fig. 8e). XRD analyses confirm that no salt minerals other than those observed in thin section were present in the unprocessed samples.

Occurrences of similar material below the crust surface include an intercalation in the upper part of the main part of the crust in one sample (site 1) (Fig. 8f), and coatings of pores in the local surface accumulation at site 2 .

\subsubsection{Surface overgrowths}

In several samples, from all sites, the surface layer is locally covered by isolated occurrences of relatively coarse-grained bloedite, often in the form of fan-like intergrowths with upward widening (Fig. 9a, 9b). It generally contains no inclusions, except in banded patterns. At least one occurrence is in optical continuity with bloedite crystals below its base.

\section{Discussion}

In this section, conclusions that can be drawn from sattelite and airborme observations are first presented. This is followed by a discussion of evaporite sedimentation based on textural features combined with mineral distribution patterns, in separate sections dealing with the precipiation of bloedite, thenardite, and other minerals.

\subsection{Processes recorded by surface characteristics}

Satellite observations demonstrate that the sampling sites are located in three different areas, representing zones with a spectrally dry (site 1), wet (site 2) and very wet (site 3) salt crust. The reflectance of the spectrally driest crust seems to be related both to its thickness and to the widespread occurrence of thenardite as a fine-grained anhydrous phase along the surface of the bloedite crust. The SPOT-5 image has only limited direct potential for mineral identification, because most spectral absorption features of hydrous sulfates are outside the satellite bandwidths, with only one spectral feature for bloedite (and gypsum) in band 4 (Drake, 1994). 
As indicated before, the SPOT-5 image is mainly useful to detect surface moisture, which causes a general decrease in spectral response from visible to middleinfrared. Surface features are mainly controlled by water sheet distribution and persistence during drying of the lake. This distribution is strongly conditioned by wind, despite the small size of the basin. The prevalent wind direction is NW to SE, which moves surface brines to the southeastern part of the basin. This ultimately results in the asymmetric concentric patterns recognized for the salt-covered basin floor in orthophotographs. The one image for a period with surface brines illustrates the rebound of the water sheet when the wind is calm, surpassing the downwind edge of the neighbouring salt crust fringe.

The striking lineaments observed in most orthophotographs are parallel to the prevalent wind direction. These features must have been created by the scouring action of the wind, removing surface salts down to the wet sediment substrate. Similar linear shallow grooves and ridges are currently observed in other lakes in the Ebro valley, where their formation is also related to wind action (C. Castañeda, unpubl. data). The lineaments clearly differ from tracks created by dragging stones or other materials into the basin from the surrounding fields (Pueyo Mur, 1978/79).

Among the five studied images, one does not display any lineaments. It represents a stage at which these parallel-linear features had not yet developed after salt crust formation during drying of the lake. Significantly, this stage is also characterized by the presence of a coarse polygonal cracking pattern, in parts with the most limited thickness of the salt crust.

\subsection{Bloedite sedimentation}

Bloedite is the dominant salt mineral in the available samples, in line with the results of earlier studies (Pueyo Mur, 1978/1979; Mingarro et al., 1981; Pérez et al., 1998). The present study, based on thin section observations, shows that the crust includes various types of bloedite occurrences which formed in different conditions, as discussed below. Types of bloedite sedimentation recognized for other lakes are not applicable to the studied basin, including transformation of an epsomite precursor $\left(\mathrm{MgSO}_{4} \cdot 7 \mathrm{H}_{2} \mathrm{O}\right)$ (Sánchez-Moral et al., 1998) and deposition from Mg-enriched brines over a thenardite-mirabilite crust (Last and Schweyen, 1983). 


\subsubsection{Coarse-grained xenotopic-hypidiotopic bloedite}

This type of bloedite deposit is the principal constituent of the main part of the crust. It partly forms by incorporative growth along the upper part of the sediment substrate, resulting in a basal part with abundant sediment inclusions and common enclosed glauberite crystals. This kind of growth has also been documented for other bloedite occurrences (Vizcayno et al., 1995; Mees and Singer, 2006). Local zoning of crystals in this part of the crust developed by alternating fast incorporative growth and slow displacive growth. The much lower sediment content of the upper part of the crust is largely related to distance from the substrate. At site 1 , nearly sediment-free bloedite that forms the basal part of the protrusions does represent a separate growth stage, evolving to co-precipitation of bloedite and thenardite. The horizontal surface of the discontinuous surface accumulation at this site, covering an undulating basal bloedite crust, probably corresponds to the brine-air interface during its formation. Its nature indicates subaqueous bottom growth for the entire coarse-grained xenotopichypidiotopic bloedite deposit. The thin horizontal plates that occur at the same site are thenardite-bloedite rafts that formed at a later stage, by settling after nucleation and growth along the surface of a shallow water body. Note that the main part of the crust, as well as all other units, shows no clear indications for reworking of salts by wind, despite the observed basin-scale impact of wind on surface characteristics.

\subsubsection{Fan-like aggregates, with downward widening}

Fan-like aggregates develop when growth of several crystals originates from a single centre. This type of growth can be an indication for poor nucleation, which is common for double-cation salts such as bloedite (Sánchez-Moral et al., 1998). Downward widening indicates that the crystals formed from brines that were available below the nucleus, where brine-saturated conditions prevailed.

\subsubsection{Fan-like aggregates, with upward widening}

Fan-like intergrowths with upward widening are a common texture for subaqueous bottom growth. This type of growth locally took place after deposition of the fine-grained surface layer, from brines that covered the surface at some stage. It also locally characterizes a relatively fine-grained layer along the surface of the main part of the unit, which also formed from surface brines. 


\subsubsection{Radial aggregates}

Radial aggregates indicate conditions in which growth can take place in all directions. This is common in subaqueous conditions, which are inferred for the local surface accumulations at site 2 . Minor occurrences with a similar texture at site 3 must have formed in the same way. Subaqueous formation has also been suggested for radial bloedite aggregates by Vizcayno et al. (1995), invoking conditions with slow crystallization. Radial aggregates with sediment inclusions in the lower part (see also Vizcayno et al., 1995) indicate that growth can be incorporative in some directions and that bottom growth can be involved.

\subsubsection{Coatings}

Coatings without sediment inclusions formed at a later stage than the surrounding bloedite mass, in conditions without sediment in contact with the evaporating brine. At least part of these bloedite occurrences formed as epitaxial overgrowths on sediment-rich bloedite around the pore, requiring no formation of nuclei that are unrelated to the covered material.

\subsubsection{Crystals in sediment matrix}

Bloedite crystals within the sediment matrix formed by evaporation of brines that the sediment contained. This partly resulted in radial and inward-widening fan-like aggregates, determined by brine distribution patterns. Bloedite occurrences along the base of the samples formed after the crust and the adhering material became separated from the substrate. Late-stage formation is also demonstrated by the local presence of enclosed gypsum crystals. Differences in texture, ranging from relatively large single crystals to fibrous radial aggregates, indicate differences in nucleation conditions and growth rates between these bloedite occurrences.

\subsection{Thenardite sedimentation}

In most earlier studies of the Mediana basin, thenardite is mentioned as salt crust component, assumed to be derived at least in part by transformation of a mirabilite precursor $\left(\mathrm{Na}_{2} \mathrm{SO}_{4} \cdot 10 \mathrm{H}_{2} \mathrm{O}\right)$ (Pueyo Mur, 1978/1979; Mingarro et al., 1981; Auqué et al., 1995; Valero-Garcés et al., 2000a, 2000b). In the sequence of mineral formation inferred for the basin, sodium sulfates are formed before bloedite precipitation (Auqué 
et al., 1995; Valero-Garcés et al., 2000a), in agreement with results of evaporation experiments (Auqué et al., 1995; López and Mandado, 2007).

In the present study, thenardite is confined to the upper part of the crust, and its abundance is much greater in the depositional centre of the basin than in more marginal areas. These features suggest that thenardite formed at a later stage than bloedite. This may initially have involved bloedite-thenardite co-precipitation following bloedite sedimentation, as no transformation is recognized for the upper part of the crust, below the fine-grained surface layer. Textural features show no indications for thenardite formation by dehydration of mirabilite, which typically produces fine-grained pseudomorphic aggregates (Pueyo Mur, 1980; Tursina et al., 1980; Vizcayno et al., 1995). However, different textures may be produced by the mechanism proposed by López and Mandado (2007) for thenardite formation from a mirabilite precursor in evaporating Mediana brines, involving subaqueous transformation by a dissolutionprecipitation reaction during brine evolution.

The small crystal size of the thin surface layer of thenardite that covers the bloedite crust indicates conditions with high nucleation rates, linked to high brine concentrations and fast evaporation. Its occurrence along the irregular surface of the crust is in principle compatible with settling of individual small crystals, and the horizontal sections that continue over various depressions suggest settling of horizontal plates that formed along the brine-air interface. However, the occurrence or continuation of fine-grained thenardite along the sides and base of various structures, including thin horizontal thenardite-bloedite plates, lateral extensions from surface protrusions, and the sample as a whole, indicates formation along the surface of preexisting deposits, rather than growth and sedimentation within the water column. The most likely process is replacement of bloedite by thenardite, which has only rarely been reported (Ordóñez et al., 1994), in contrast to the reverse reaction (Mees, 1999; Li et al., 2010; Mees \& Tursina, 2010). The cause of the common separation between the layer and the crust is not apparent. It is not related to the loss of highly soluble salts during thin section preparation, whose absence is confirmed by XRD analysis, and there are also no indications for volume loss by transformation of a precursor mineral such as mirabilite.

Overall, the fine-grained thenardite-dominated material represents a recent surface deposit, whose presence is responsible for the white appearance of the crust 
surface in hand specimens. Local occurrences of similar material as intercalations correspond to buried surface levels.

\subsection{Formation of other minerals}

Minerals other than bloedite and thenardite that have been detected both by the present study and by earlier investigations are gypsum, glauberite and halite, as discussed below. The presence of hexahydrite $\left(\mathrm{MgSO}_{4} \cdot 6 \mathrm{H}_{2} \mathrm{O}\right)$ (Pérez et al., 1998) could not be confirmed.

Halite has been commonly reported (Pueyo Mur, 1978/1979; Mingarro et al., 1981; Pérez et al., 1998; Valero-Garcés et al., 2000a), although local brines have a relatively low chloride content. In the present study, the presence of halite is confined to minor occurrences in samples of the material adhering to the base of the crust, which probably formed by drying of interstitial solutions.

Gypsum (Pueyo Mur, 1978/1979; Mingarro et al., 1981; Valero-Garcés et al., 2000a) and glauberite (Mingarro et al., 1981) have been reported as salt crust components at Mediana, whereby these minerals are considered to have formed as part of a sequence that ultimately results in bloedite-thenardite precipitation (Auqué et al., 1995; Valero-Garcés et al., 2000a; López and Mandado, 2007). These minerals are in fact part of the sediment underlying the crust, which is also documented by other analyses of the mud below the salt crust (Mingarro et al., 1981; Pérez et al., 1998; Valero-Garcés et al., 2000a). The deposition of this sediment and the sulfate minerals it contains is unrelated to the development of the bloedite-dominated salt crust. Based on observations for the available samples, from three sampling sites, no lateral trends are recognized for the composition of salts in the sediment below the crust, in contrast to other lakes with a similar $\mathrm{Na}-\mathrm{Ca}-\mathrm{SO}_{4}$ association (Hardie, 1968). If glauberite and gypsum formed during accumulation of the calcareous sediment in which they occur, glauberite precipiation following a stage with gypsum formation is recorded by the vertical sequence that is observed for one site. A temporal relationship is also recognized for the sample in which gypsum crystals are enclosed by bloedite, whereby the latter occurs as a late stage diagenetic phase.

Eugsterite has not previously been detected in the basin, and it hence has never been considered in geochemical modelling of brine evolution (Auqué et al., 1995; López and Mandado, 2007). Eugsterite is a fairly common mineral in salt efflorescences 
(Mees and Tursina, 2010), where it forms as a subaerial precipitate. At Mediana, a similar nonsubaqueous mode of formation is possible for the eugsterite occurrence below the crust, where it commonly contains an admixture of fine calcareous sediment and quartz grains. However, its presence as mineral inclusions with associated sediment inclusions in the overlying bloedite crust suggests that it was simply incorporated during later bloedite crystallization. In contrast, its common occurrence in higher parts of the crust, with very low sediment content, indicates co-precipitation of eugsterite and bloedite, together with thenardite in part of the basin.

\section{Conclusions}

Salt crusts in the studied basin are strongly bloedite-dominated, which could be seen as an indication that they formed during a single stage. However, textural features document a great complexity, whereby various processes contribute to the development of the present fabric of the crust. Subordinate occurrences of other salt minerals provide a further record of sedimentary and diagenetic processes in seasonally dry or ephemeral salt lakes. Airborne data confirm the occurrence of spatial textural variability of the surface crust, and they also demonstrate that distribution patterns vary with time, indicating the need for periodic monitoring and sampling to fully understand evaporite sedimentation in lakes of this type.

\section{Acknowledgements}

This study was funded by project AGL2009-08931 of the Spanish Ministry for Science and Education, and by project G.0103.05N of the Fund for Scientific Research (Flanders).

\section{References}

Auqué, L.F., Vallés,V., Zouggari, H., López, P.L., Bourrié, G., 1995. Geoquímica de las lagunas saladas de Los Monegros (Zaragoza). I. Determinación experimental de los efectos del reequilibrio mirabilita-solución con la temperatura en un sistema natural. Estudios Geológicos 51 (243), 257. 
Castañeda, C., Herrero, J., Casterad, M.A., 2005. Facies identification within the playalakes of the Monegros Desert, Spain, with field and satellite data. Catena 63, 3963.

Díaz de Arcaya, N., Castañeda, C., Herrero, J., Losada, J.A., 2005. Cartografía de coberturas asociadas a las fluctuaciones de la Laguna de Gallocanta. Revista de la Asociación Española de Teledetección 24, 61-65.

Drake, N.A., 1994. Reflectance spectra of evaporite minerals (400-2500 nm): applications for remote sensing. International Journal of Remote Sensing 16, $2555-2571$.

Garrett, D.E., 2001. Sodium Sulfate. Handbook of Deposits, Processing, Properties, and Use. Academic Press, San Diego, 365 pp.

González-Audícana, M., Otazu, X., Fors, O., Álvarez-Mozos, J., 2006. A low computationalcost method to fuse IKONOS images using the spectral response function of its sensors. IEEE Transactions on Geoscience and Remote Sensing 44, 1683-1691.

Hardie, L.A., 1968. The origin of the recent non-marine evaporite deposit of Saline Valley, Inyo County, California. Geochimica et Cosmochimica Acta 32, 12791301.

Karpychev, Y., 2007. Variations in the sedimentation in Kara Bogaz Gol Bay related to sea level fluctuations during the Novocaspian time. Oceanology 47, 857-864.

Last, W.M., 1990. Paleohydrology and paleochemistry of Ceylon Lake, Canada. Journal of Paleolimnology 4, 219-228.

Last, W.M., 1993. Geolimnology of Freefight Lake: an unusual hypersaline lake in the northern Great Plains of western Canada. Sedimentology 40, 431-448.

Last, W.M., Ginn, F.M., 2005. Saline systems of the Great Plains of western Canada: an overview of the limnogeology and paleolimnology. Saline Systems 1 (10), 38 pp.

Last, W.M., Schweyen, T.H., 1983. Sedimentology and geochemistry of saline lakes of the Great Plains. Hydrobiologia 105, 245-263.

Li, M., Fang, X., Yi, C., Gao, S., Zhang, W., Galy, A., 2010. Evaporite minerals and geochemistry of the upper $400 \mathrm{~m}$ sediments in a core from the Western Qaidam Basin, Tibet. Quaternary International 218, 176-189.

López, P.L., Mandado, J.M., 2007. Experimental evaporation of superficial brines from continental playa-lake systems located in Central Ebro Basin (northeast Spain). In: 
Schreiber, B.C., Lugli, S., Babel, M. (Eds.), Evaporites through Time and Space. Geological Society Special Publication 285, 143-154.

Lowenstein, T.K., Hardie, L.A., 1985. Criteria for the recognition of salt-pan evaporites. Sedimentology 32, 627-644.

Marqués, L.A., Santos, J.A., Esnaola, J.M., Gil, C., 1991. Mapa Geológico de España, 1:50.000, Hoja ${ }^{\circ}$ 384, Fuentes de Ebro. Instituto Geológico y Minero de España, Madrid, Spain, 42 pp.

Mees, F., 1999. Textural features of Holocene perennial saline lake deposits of the Taoudenni-Agorgott basin, northern Mali. Sedimentary Geology 127, 65-84.

Mees, F., 2001. The development of a burkeite-dominated salt crust - an example of evaporate sedimentation in a saline pan with non-monomineralic deposits. Sedimentology 48, 1225-1233.

Mees, F., Singer, A., 2006. Surface crusts on soils/sediments of the southern Aral Sea basin,Uzbekistan. Geoderma 136, 152-159.

Mees, F., Tursina, T.V., 2010. Salt minerals in saline soils and salt crusts. In : Stoops, G., Marcelino, V., Mees, F. (Eds.), Interpretation of Micromorphological Features of Soils and Regoliths. Elsevier, Amsterdam, pp. 441-469.

Mingarro, F., Ordoñez, S., López de Azcona, M.C., Garcia del Cura, M.A., 1981. Sedimentoquímica de las lagunas de Los Monegros y su entorno geológico. Boletín Geológico y Minero 92, 171-195.

Ordóñez, S., Sánchez-Moral, S., García del Cura, M.A., Rodríguez Badiola, E., 1994. Precipitation of salts from $\mathrm{Mg}^{2+}-(\mathrm{Na}+)-\mathrm{SO} 4$ 2--Cl- playa lake brines: the endorheic saline ponds of La Mancha, central Spain. In : Renaut, R.W., Last, W.M. (Eds.), Sedimentology and Geochemistry of Modern and Ancient Saline Lakes. SEPM Special Publication 50, 61-71.

Pérez, A., Sánchez, J.A., Muñoz, A., Coloma, P., Mayayo, M.J., 1998. Génesis de los depósitos holocenos desarrollados en la laguna salada 'La Sulfúrica' de Mediana de Aragón, Provincia de Zaragoza. Geogaceta 24, 247-250.

Pueyo Mur, J.J., 1978/1979. La precipitación evaporítica actual en las lagunas saladas del área : Bujaraloz, Sástago, Caspe, Alcañiz y Calanda (provincias de Zaragoza y Teruel). Revista del Instituto de Investigaciones Geológicas 33, 5-56.

Pueyo Mur, J.J., 1980. Procesos diagenéticos observados en las lagunas tipo playa de la zona Bujaraloz-Alcañiz (provincias de Zaragoza y Teruel). Revista del Instituto de Investigaciones Geológicas 34, 195-207. 
Quirantes, J., 1978. Estudio Sedimentológico y Estratigráfico del Terciario Continental de Los Monegros. Institución Fernando el Católico, Zaragoza, Publication $n^{\circ} 178$, 207 pp.

Sack, L.A., Last, W.M., 1994. Lithostratigraphy and recent sedimentation history of Little Manitou Lake, Saskatchewan, Canada. Journal of Paleolimnology 10, 199212.

Salvany, J.M., 2009. Geología del Yacimiento Glauberítico de Montes de Torrero (Zaragoza). Prensas Universitarias de Zaragoza, Spain, 80 pp.

Sánchez-Mejorada, P., 1986. Evaporite deposit of Laguna del Rey. AIME Transactions of the Society of Mining Engineers 280, 1923-1927.

Sánchez-Moral, S., Ordóñez, S., García del Cura, M.A., Hoyos, M., Cañaveras, J.C., 1998. Penecontemporaneous diagenesis in continental saline sediments: bloeditization in Quero playa lake (La Mancha, Central Spain). Chemical Geology 149, 189-207.

Tursina, T.V., Yamnova, I.A., Shoba, S.A., 1980. Combined stage-by-stage morphological, mineralogical and chemical study of the composition and organization of saline soils. Soviet Soil Science 12, 81-94.

Valero-Garcés, B.L., Delgado-Huertas, A., Navas, A., Machín, J. González-Sampériz, P., Kelts, K., 2000a. Quaternary palaeohydrological evolution of a playa lake: Salada Mediana, central Ebro Basin, Spain. Sedimentology 47, 1135-1156.

Valero-Garcés, B.L., González-Sampériz, P., Delgado-Huertas, A., Navas, A., Machín, J., Kelts, K., 2000b. Lateglacial and Late Holocene environmental and vegetational change in Salada Mediana, central Ebro Basin, Spain. Quaternary International 73/74, 29-46.

Vizcayno, C., García-González, M.T., Gutiérrez, M., Rodríguez, R., 1995. Mineralogical, chemical and morphological features of salt accumulations in the Flumen-Monegros district, NE Spain. Geoderma 68, 193-210.

Warren, J.K., 2006. Evaporites. Sediments, Resources and Hydrocarbons. SpringerVerlag, Berlin, 1035 pp.

Warren, J.K., 2010. Evaporites through time: Tectonic, climatic and eustatic controls in marine and nonmarine deposits. Earth-Science Reviews 98, 217-268. 


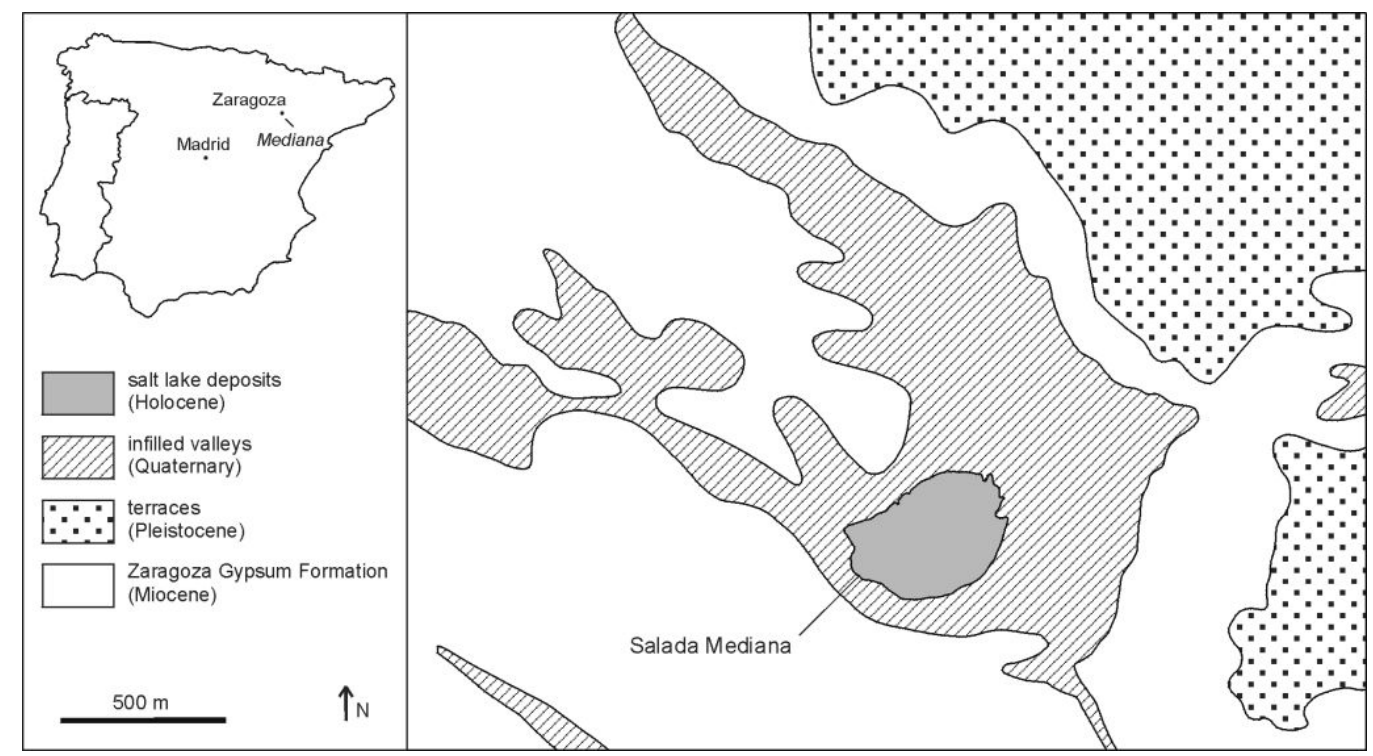

Figure 1. Location and setting of the Salada Mediana basin (geological features modified from Marqués et al., 1991).
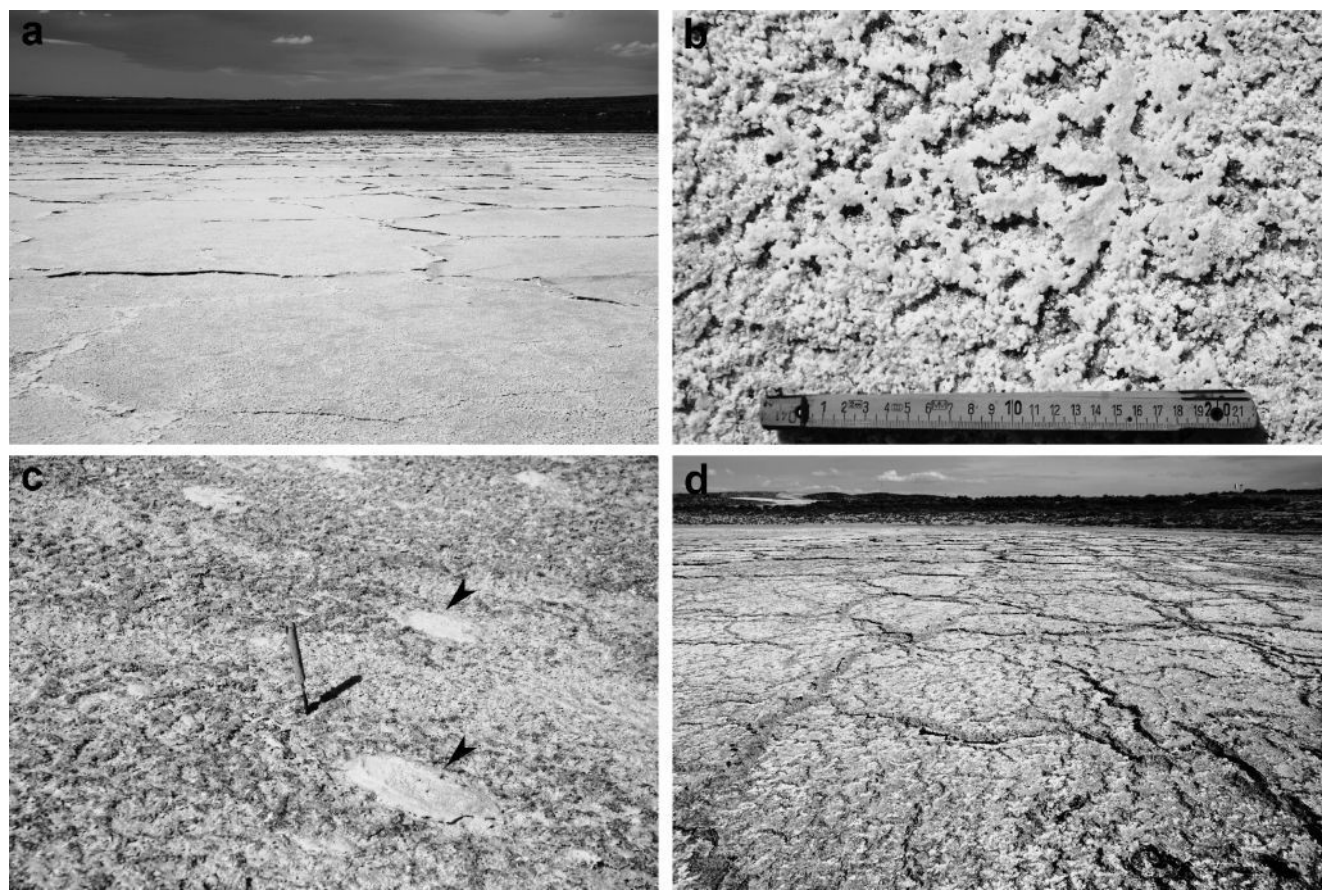

Figure 2. Macroscopic features of the Salada Mediana crust at the sampling sites. (a) White crust with polygonal pattern (site 1). (b) Crust including a white surface deposit with horizontal surface and irregular patterns (site 1). (c) Crust with scattered white surface accumulations (arrows) (site 2). (d) Greyish crust with polygonal pattern (site 3). 


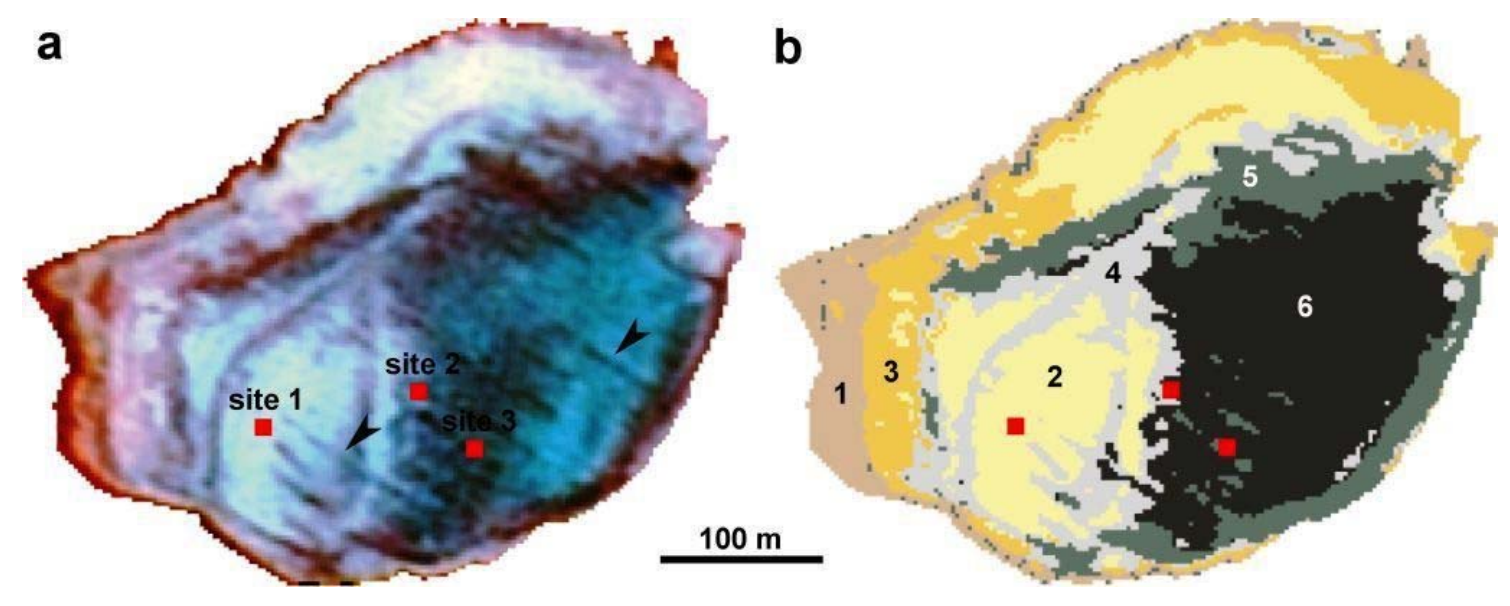

Figure 3. SPOT-5 image, September 30 2008. (a) RGB 432 false colour composite; white tones indicate spectrally dry crust, and dark tones represent low reflectance due to the presence of moisture; dry soil is indicated in red; lineaments indicated by arrows. (b) ISODATA classification of the same image in six classes : dry soil (1), and five crust classes from driest (2) to wettest (6).
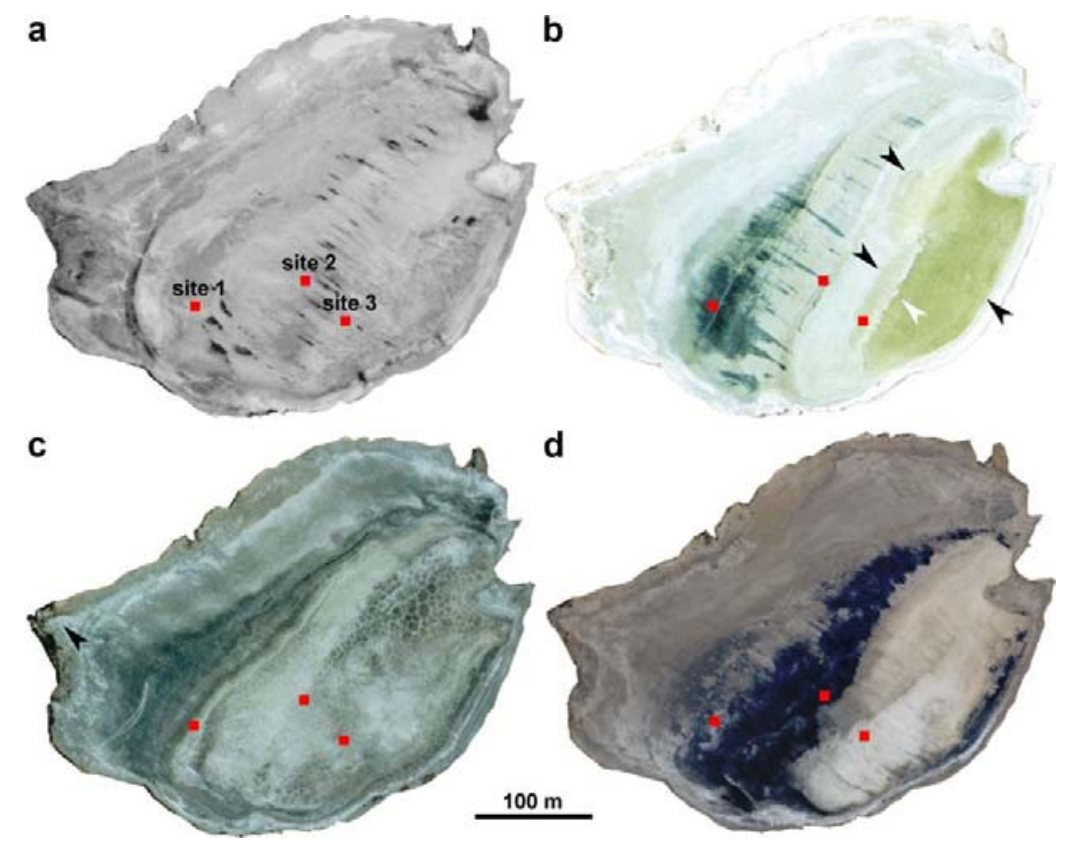

Figure 4. Orthophotographs. (a) Black-and-white, October 1997. (b) Panchromatic, June 2000 (black arrows indicate edge of surface water, white arrow indicates salt crust edge). (c) Panchromatic, August 2006 (arrow indicates main runoff inlet). (d) Panchromatic, June 2009. 


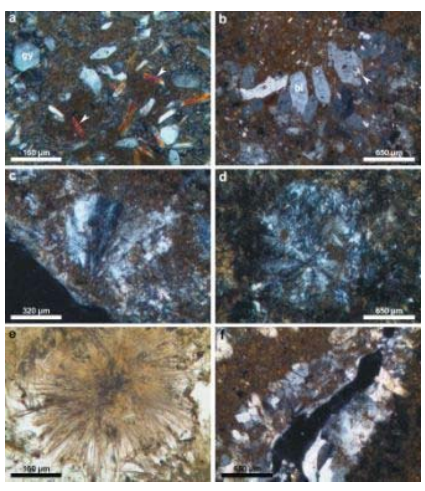

Figure 5. Material below the crust. (a) Euhedral tabular gypsum crystals (gy) and euhedral glauberite crystals (arrows) (site 3, cross-polarized light [XPL]). (b) Subhedral elongated bloedite crystals (bl), with some enclosed gypsum crystals (arrow) (site 1, XPL). (c) Fan-like bloedite aggregate, widening away from the side of the sample (site 1, XPL). (d) Bloedite with fibrous aspect, partly as radial aggregates (site 2, XPL). (e) Radial eugsterite aggregate (site 3, plane-polarized light [PPL]). (f) Bloedite coating along the sides of a pore (site 1, XPL).

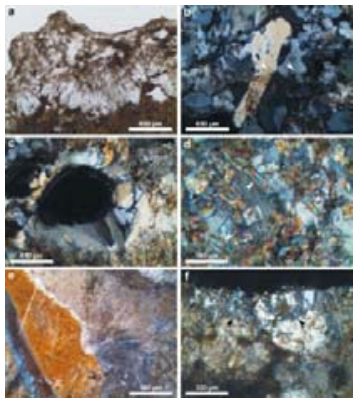

Figure 6. Main part of the crust. (a) Section largely composed of fan-like intergrowths of elongated bloedite crystals, with downward widening of the aggregate (site 1, PPL). (b) Boundary between lower part with high sediment content and upper part with low sediment content, crossing large bloedite crystals (arrows) (site 1, XPL). (c) Bloedite coating without sediment inclusions, composed of crystals that are partly in optical continuity with the sediment-rich bloedite along the sides of the pore (site 3, XPL). (d) Euhedral glauberite crystals (arrows) enclosed in bloedite (site 3, XPL). (e) Acicular eugsterite crystals in bloedite, partly as radial aggregates (site 1, XPL). (f) Fine-grained surface interval, composed of parallel elongated crystals (base indicated by arrows), locally with upward widening (site 3, XPL). 


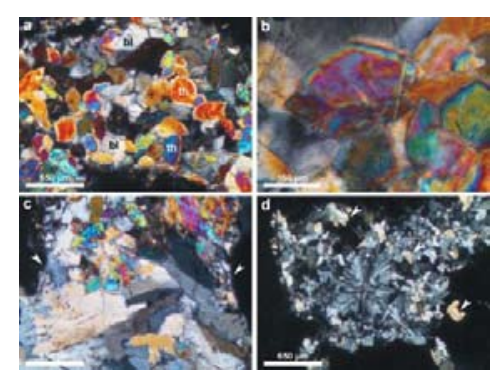

Figure 7. Upper part of the crust and equivalent intervals. (a) Deposit composed of thenardite (th) and bloedite (bl) (site 1, XPL). (b) Thenardite and bloedite, containing acicular eugsterite inclusions, partly in the form of radial aggregates (site 1, XPL). (c) Lower part of protrusion on the salt crust surface, with thenardite occurrence largely confined to the upper part (arrows indicate edges of the structure) (site 1, XPL). (d) Surface accumulation composed of thenardite (arrows) and bloedite, the latter commonly as radial aggregates (site 2, XPL; thinner thin section than for most other samples).

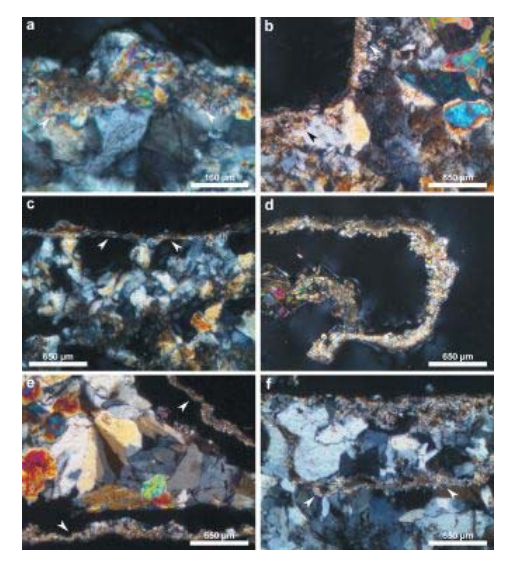

Figure 8. Surface layer. (a) Typical aspect of the fine-grained thenardite surface deposit (base indicated by arrows) (site 3, XPL). (b) Surface layer lining the vertical side of a protrusion (white arrow) and continuing along the adjacent horizontal section (black arrow) 29 (site 1, XPL). (c) Surface layer extending over the space between higher parts of the crust surface (arrows) (site 3, XPL). (d) Edge of a surface layer occurrence that lines a hollow structure (site 1, XPL). (e) Surface layer (arrows), along the top and bottom of a thenarditebloedite raft (site 1, $\mathrm{XPL}$ ). (f) Buried surface layer near the top of the crust (arrows), parallel to the surface, which is covered by a similar fine-grained thenardite deposit (site 1, XPL). 


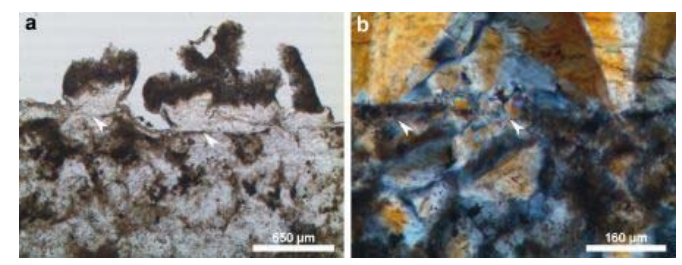

Figure 9. Surface overgrowths. (a) Local bloedite occurrence along the crust surface (arrows), without inclusions in the lower part and high content in the upper part, with sawtooth pattern along base (site 1, PPL). (b) Detail of the base of the same occurrence, showing the continuation of the thenardite-bearing surface layer along the base of the overgrowth (arrows) and illustrating the fan-like arrangement of the bloedite crystals (site 1, XPL). 